\title{
A Photovoltaic System for a Farm in Khon Kaen Province
}

\author{
Pitiphong Naktamna ${ }^{1}$, Panhathai Buasri ${ }^{2}$,Wiroj Taweepworadej ${ }^{3}$ \\ ${ }^{1}$ Graduate School, Khon Kaen University, Khon Kaen, Thailand \\ ${ }^{2,3}$ Faculty of Engineering, Khon Kaen University, Khon Kaen, Thailand
}

\begin{abstract}
This paper presents a photovoltaic (PV) system for lighting load of a small farm in Khon Kaen province, THAILAND. PV energy production was estimated through outdoor experimentation of a PV module at latitude $16^{\circ} 26^{\prime} \mathrm{N}$ longitude $102^{\circ} 49^{\prime} \mathrm{E}$. The standalone PV system with battery to supply lighting loads in a small farm was designed considered two types of light bulbs, LEDs and compact fluorescent (CFL). Information is useful for PV design for small animal farm, agriculture and energy saving applications.
\end{abstract}

Keywords: Battery, LED, photovoltaic system, renewable energy, standalone.

\section{Introduction}

Thailand has great potential in electricity production from solar energy because the location is in Southeast of Asia which locates near the equator. Solar energy produces electricity with no pollution and has no negative environmental effects, making it an attractive option for on-grid and off-grid PV systems.

General PV System design requires mainly weather data such as solar irradiance in $\mathrm{W} / \mathrm{m}^{2}$, ambient temperature in Celsius scale and peak sun hours (Rajeswari \& Bhanu, 2013). Past PV energy production data or historic solar energy data at desired site were analysed by several researchers (Hernández-Callejo et al., 2019) (H A Alwaeli et al., 2016). PV energy production of the large on-grid PV system needs precisely prediction methods to estimate yearly energy production and computer programming with complex algorithm with high cost were implemented. Daily solar irradiation prediction needs at least 70 days to 1 year data were recorded results in around 90\% accuracy (H A Alwaeli et al., 2016) (Bataineh \& Dalalah, 2012) (Gont, 2019) (Bhuiyan \& Ali Asgar) (Ghafoor \& Munir, 2015) (Shukla et al., 2016) (Sasittharanuwat et al., 2006) (Abu-Zarifa, 2014). Standalone PV system design is simple and didn't need high accuracy. Energy production only needs to provide sufficient electricity to loads.

Average solar irradiance at Bangkok recorded for 22 years of $5.23 \mathrm{kWh} / \mathrm{m}^{2}$ or peak sun hours of 5.23 hours at $1 \mathrm{~kW} / \mathrm{m}^{2}$ was specified and the least peak sun hours in November are 4.80 hours. In (Atthasongkhro et al., 2013), authors measured the maximum daily Global radiation recorded during 1970-2010 at latitudes close to $15^{\circ} \mathrm{N}$ based on 5 stations in THAILAND, 
authors found that Khon Kaen station absorbed solar radiation about 17-27 MJ/m² day $(4.722$ $-7.500 \mathrm{kWh} / \mathrm{m}^{2}$ day) or 4.8-7.5 peak sun hours (Abu-Zarifa, 2014) (Barua et al., 2017) (Solar Insolation Map. n.d) (Atthasongkhro et al., 2013). Electricity can be used at night by battery storage for a standalone PV system.

In Thailand, there are dairy farms in many rural areas of the country. A dairy farm needed electrical energy to supply mechanical loads and lighting loads to do activity in the farm during the day and night. Bill payment on electricity reduction by the use of renewable energy in farms gain more attentions recently due to global warming issues.

This paper presents a photovoltaic system design for a small farm in Khon Kaen, THAILAND. Energy production was estimated for a standalone photovoltaic system with battery to supply lighting loads in a small farm. In this work, a PV design of small farm at latitude $16^{\circ} 26^{\prime} \mathrm{N}$ longitude $102^{\circ} 49^{\prime} \mathrm{E}$ considered the actual PV module data by outdoor tests. The PV system design was presented and number of devices are reported for CFL and LED light bulbs.

\section{PV SYSTEM}

\subsection{Standalone PV System configuration}

Main devices in a standalone PV system are PV array, a DC/DC solar charger and an inverter. Battery storage is an optional power supply or back-up unit for providing extra energy to DC or AC load.

Some sizing PV array plans required the solar radiation data or power generation data at the point of PV installation. On a cloudy day PV power is reduced to be as low as $20 \%$ compared to a sunny day. Solar irradiance data are insufficient in rural areas. Moreover, the manufacturer data such as operating voltage and current, efficiency, power variation on temperature are not provided and sometimes less information given by PV manufacturers in THAILAND. Therefore a PV module should be tested under actual weather conditions at the site to obtain actual data.Basic standalone PV system shown in Figure 1 is considered in this work.

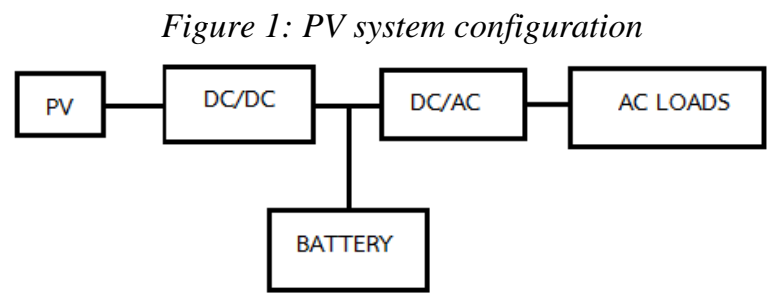

PV array converted solar energy to DC electricity during the day. To receive high solar radiance, Fixed PV array should set tilt angle to location's latitude or \pm 10 degree and facing south. Solar radiance in $\mathrm{W} / \mathrm{m}^{2}$ varies from sunrise to sunset per day depends on season, time of day and weather conditions. Maximum Solar radiance at $1000 \mathrm{~W} / \mathrm{m}^{2}$, called peak sun, is the maximum solar intensity per area of $1 \mathrm{~m}^{2}$ around noon. Peak sun hours are number of hours considered peak sun for a typical day. The average peak sun-hours (PSH) any location may be 3-4 hours. Khon Kaen has 5.0-5.9 peak sun hours during the worst month of a year 
with suitable tilt angle. On the worst month solar energy is $16 \mathrm{MJ}$ given $4.44 \mathrm{~kW} / \mathrm{m}^{2}$ or 4.4 PSH.

A DC/DC converter or a solar charger is needed for supplying DC load or battery storage. To feed electricity to load at night, battery capacity must have the usable energy about 40-60\% for depth of discharge battery. PV power was fed to battery and load during the day and battery supplies load at night. DC/DC converter with a microcontroller can control the recharging and discharging processes of battery. A DC/AC or an inverter converts DC to AC current for a $220 \mathrm{~V}$ AC load. At night or when solar radiation is low, battery storage supplies the stored energy until reaching its limitation.

PV system energy path efficiency can be presented as the follows;

$$
\eta_{p}=\frac{E_{d}}{E_{p v}}
$$

Where

$\eta_{p}$ is PV system energy path efficiency including DC/DC DC/AC efficiencies.

$E_{d}$ is daily load demand in KWH.

$E_{p v}$ is daily $\mathrm{PV}$ energy production per array.

Efficiency of a converter ranges $80 \%-95 \%$.

Without long term solar irradiance data, PV energy production per array can be simply determined from estimated by the real tested PV module $\left(P_{e}\right)$ and the average peak sun hour .

$$
E_{p v}=P_{e} \cdot H_{p s}
$$

Usable battery capacity must provide energy to load at night from the day charging battery by PV array. Small battery with oversized battery is desirable in practical because battery can get fully charged often. One day recharging battery is used in this work.

Battery capacity can be calculated for AC loads as presented as in the following,

$$
\begin{gathered}
E_{b}=E_{b u}+E_{b 0} \\
E_{b u}=\eta_{c h} E_{p v}=\frac{E_{d}}{\eta_{d i s}} \\
D O D=\frac{E_{b u}}{E_{b}}
\end{gathered}
$$

Where $D O D$ is depth of discharge for the battery, the usable capacity to fully charged battery capacity, normally equals to 0.8 .

Then battery capacity can be determined as, 


$$
E_{b}=\frac{\eta_{c h} \cdot E_{p v}}{D O D}
$$

A small PV system operates at $12 \mathrm{~V}$ or $24 \mathrm{~V}$ battery voltage. Battery is rated in Ah, capacity in Wh and cell voltage. Battery capacity can be calculated by,

$$
E_{b}=N_{b} \cdot V_{s} \cdot A h
$$

Where

$N_{b}$ is number of battery cells.

Figure 2: PV system diagram

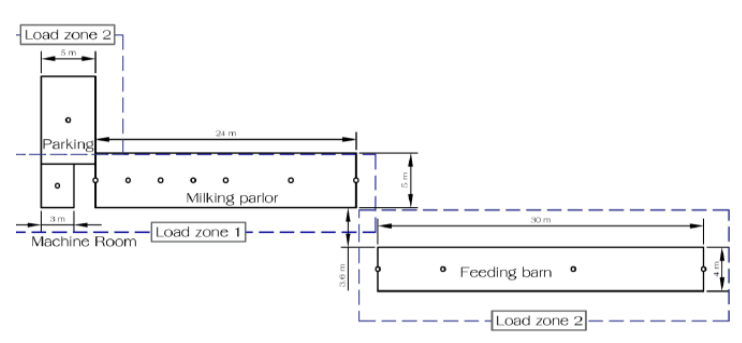

Figure 3: Feeding barn

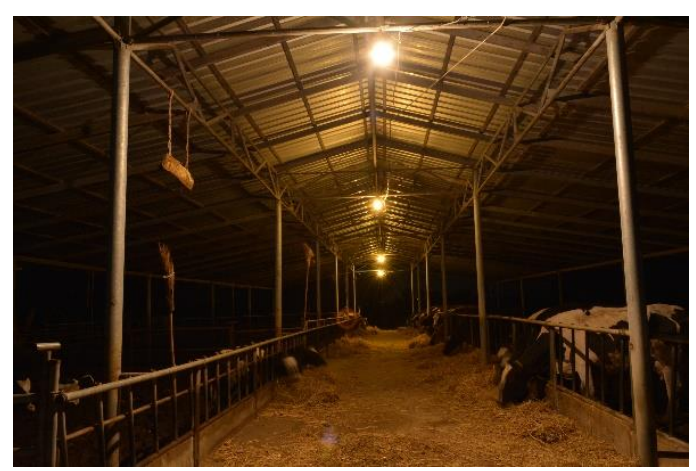

\subsection{Load demand}

Main parts in a standalone PV system are a PV array, a solar charger and an inverter. Battery storage is an optional power supply or back-up unit for providing extra energy during low sunlight. 


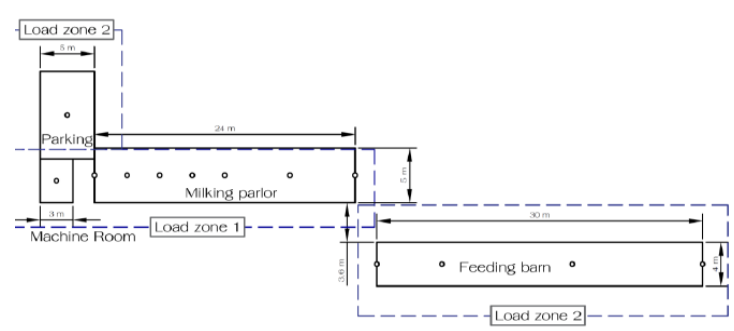

Table 1: CEL Load Data

\begin{tabular}{|l|l|l|l|l|l|}
\hline Activity Room & AC Loads & Qty. & Time & Power (W) & Energy (WH) \\
\hline Milking & CFL 25 W & 7 & 6AM-7.30AM & 175 & 262.5 \\
\hline Machine & CFL 25 W & 1 & 6AM-7.30AM & 25 & 37.5 \\
\hline Parking & CFL 65 W & 1 & 6 AM-6PM & 65 & 780 \\
\hline Feeding & CFL 25 W & 4 & 6 AM-6PM & 100 & 1200 \\
\hline \multicolumn{7}{|l}{} & Total per day & 365 & 2280 \\
\hline
\end{tabular}

Figure 5: Load profile

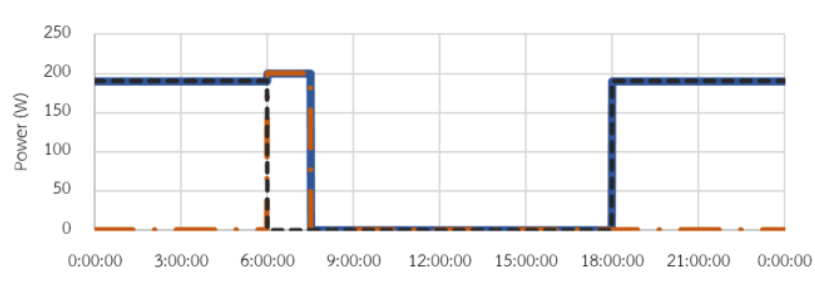

Several LEDs in Thailand whole sales are listed in Table 2, The exchange rate of 1 USD is 30.24 Baht on January 10, 2019. If CFL light bulbs are replaced with E27 LEDs. Load data can be specified as shown in Table 3 .

Table 2: LED data

\begin{tabular}{|l|l|l|l|}
\hline Type & Power $(\mathrm{W})$ & Cost in Thai Bath & Cost in \$USD \\
\hline CFL & 14 & 145 & 4.79 \\
\hline CFL & 8 & 99 & 3.27 \\
\hline CFL & 45 & 550 & 18.19 \\
\hline CFL & 20 & 179 & 5.92 \\
\hline LED & 12 & 390 & 12.90 \\
\hline LED & 65 & 249 & 8.23 \\
\hline LED & 6 & 150 & 4.96 \\
\hline LED & 4 & 140 & 4.63 \\
\hline
\end{tabular}


Table 3:LED Load Data

\begin{tabular}{|l|l|l|l|l|l|}
\hline Activity Room & AC Loads & Qty. & Time & Power $(\mathrm{W})$ & Energy $(\mathrm{Wh})$ \\
\hline Milking & LED 20 W & 7 & 6AM-7.30AM & 140 & 210 \\
\hline Machine & LED 20 W & 1 & 6AM-7.30AM & 20 & 30 \\
\hline Parking & LED 20 W & 1 & 6 AM-6PM & 20 & 240 \\
\hline Feeding & LED 20 W & 4 & 6 AM-6PM & 80 & 960 \\
\hline \multicolumn{7}{|l}{} & Total per day & 260 & 1440 \\
\hline
\end{tabular}

\subsection{PV production data}

A polycrystalline PV module, SLP100-12, was tested outdoor at $4^{\text {th }}$ floor of the Electrical Engineering building, Khon Kaen University, Thailand, latitude $16^{\circ} 26^{\prime} \mathrm{N}$ longitude $102^{\circ} 49^{\prime} \mathrm{E}$. The PV module was tilted 17 degrees facing south.

PV power output depends on solar irradiance, temperature, efficiency of PV, time of day, and location. Solar irradiance is the main factor affected the PV current. Global, direct and diffuse irradiance can be calculated by Chenni for average monthly (Bataineh and Dalalah, 2012). However Khon Kaen province located in rural area with no accuracy solar radiance data. Data recorded at Bangkok were used for estimation PV energy at Khon Kaen. Moreover a PV module was tested on 1, 3, 5 august 2019. Experimental data were presented in Table 4.

Table 4: PV testing data

\begin{tabular}{|l|c|c|c|c|}
\hline Day of year & Date & $\mathrm{P}_{\max }(\mathrm{W})$ & $\mathrm{P}_{\text {avg }}(\mathrm{W})$ & Energy $(\mathrm{WH} /$ day $)$ \\
\hline 213 & $1 / 8 / 2019$ & 93 & 29 & 352 \\
\hline 215 & $3 / 8 / 2019$ & 86 & 33 & 403 \\
\hline 217 & $5 / 8 / 2019$ & 81 & 28 & 331 \\
\hline Average & 87 & 30 & 362 \\
\hline
\end{tabular}

Characteristics and detail of the SLP100-12 PV module are presented in Table 5.

Table 5: PV module characteristic data

\begin{tabular}{|l|c|}
\hline List & $\begin{array}{l}\text { Specification at STC }\left(1000 \mathrm{~W} / \mathrm{m}^{2}, \text { AM }\right. \\
\left.1.5 \text { spectrum, } 25^{\circ} \mathrm{C}\right)\end{array}$ \\
\hline Model Number & SLP100-12 \\
\hline Max power & $100 \mathrm{~W}$ \\
\hline Voltage at the maximum power point & $17.2 \mathrm{~V}$ \\
\hline Current at the maximum power point & $5.81 \mathrm{~A}$ \\
\hline Open Circuit Voltage & $21.6 \mathrm{~V}$ \\
\hline Short Circuit Current & $6.46 \mathrm{~A}$ \\
\hline
\end{tabular}

\subsection{Balance-of-system (BOS)}

DC/DC, inverter, battery, fuses, circuit breaker, wiring are balance of system (BOS) of the PV system. There are losses in the PV system resulted in lower PV power production. Typical DC/DC efficiency and inverter efficiency are 85\%-90\%. 


\subsection{PV System Design}

To design PV system, number of PV modules and battery capacities were calculated. PV system with minimum battery capacity was selected.

\section{Results}

The parameters used in the calculation are shown in Table 6. Results of the calculation using Eq. 1 - Eq. 7 for CFL and LED light bulbs are presented as Table 7.

Table 6: Parameter of PV system design.

\begin{tabular}{|l|c|}
\hline Detail & Value \\
\hline The daily average PV energy per module of the worst month $(\mathrm{kWh})$ & 0.362 \\
\hline Battery (Ah) & 100 \\
\hline Battery voltage per cell (V) & 12 \\
\hline Battery DOD (\%) & 70 \\
\hline DC/DC efficiency (\%) & 85 \\
\hline Inverter efficiency (\%) & 85 \\
\hline System Voltage (V) & 24 \\
\hline
\end{tabular}

Table 7: Result of PV system design.

\begin{tabular}{|l|c|c|c|}
\hline Detail of Design System & CFL & LED & Value \\
\hline Number of PV modules & 8 & 6 & 1.33 \\
\hline Number of battery cells & 4 & 2 & 1 \\
\hline Energy Prediction per year $(\mathrm{kWh})$ & 1401.6 & 1051.2 & 1.33 \\
\hline
\end{tabular}

PV modules of 8 and 6 were determined for CFL lighting and LED lighting, respectively. Other power electronic devices were similar and can be expanded the capacity in the future. $\mathrm{PV}$ production per module of $362 \mathrm{Wh}$ for a $100 \mathrm{~W}$ module was presented. Battery capacity for CFL lighting needs 2 times more than that of LED lighting. PV system with LEDs has lower battery capacity is preferable for low maintenance and investment cost of battery.

\section{Conclusion}

PV power on actual test produced electricity lower than standard test conditions in Khon Kaen province was presented in this study. Standalone PV systems with battery for both CFL and LED lighting were designed. PV system with LEDs has lower number of PV modules and battery capacities. The information is useful for PV design for animal farm, agriculture and energy saving applications. 


\section{References}

[1] Rajeswari, L. R. and Bhanu, C. V. K. (2013). Design of Stand-Alone Photovoltaic System - A Case Study. International Journal of Engineering Research and Applications, vol. 3, no. 2 , pp. $510-515$.

[2] Hernández-Callejo, L., Gallardo-Saavedra, S. and Alonso-Gómez, V. (2019). “A review of photovoltaic systems: Design, operation and maintenance”. Solar Energy, vol. 188, pp. $426-440$.

[3] H A Alwaeli, A., A Kazem, H. and T Chaichan, M. (2016). Review and design of a standalone PV system performance. International Journal of Computation and Applied Sciences, vol. 1, no. 1, pp. 1-6.

[4] Bataineh, K. and Dalalah, D. J. (2012). Optimal Configuration for Design of Stand-Alone PV System, Smart Grid and Renewable Energy, vol. 3, no.2, pp. 139-147.

[5] Gont, S. D. (2019). Design of a Standalone Photovoltaic System for a Typical Household around Dessie City-Ethiopia, American Journal of Electrical and Electronic Engineering, vol. 7, no. 1, pp. 1-7.

[6] Bhuiyan, M. M. H. and Ali Asgar, M. (2003). Sizing of a stand-alone photovoltaic power system at Dhaka. Renewable Energy, vol. 28, pp. 929-938.

[7] Ghafoor, A. and Munir, A. (2015). Design and economics analysis of an off-grid PV system for household electrification. Renewable and Sustainable Energy Reviews, vol. 42, pp. 496-502.

[8] Shukla, A. K., Sudhakar, K. and Baredar, P. (2016). "Design, simulation and economic analysis of standalone roof top solar PV system in India". Solar Energy, vol. 136, pp. 437449.

[9] Sasitharanuwat, A., Rakwichian, W. and Nipon Ketjoy, S. Y. (2006). Designs and Testing of a $10 \mathrm{kWp}$ Standalone PV Prototype for Future Community Grid Adapted for Remote Area in Thailand. International Journal of Renewable Energy, vol. 1, no. 2, 31-43.

[10] Abu-Zarifa, A. (2014). System Design of Photovoltaic-Solar Home Lighting for Household in Gaza Strip. International Conference on Geological and Environmental Sciences. Singapore, vol. 73, no. 14.

[11] Barua, S., Prasath, R. A. and Boruah, D. (2017). Rooftop solar photovoltaic system design and assessment for the academic campus using PVsys software. International Journal of Electronics and Electrical Engineering. vol. 5, No.1, pp. 76-83.

[12] Solar Insolation Map. (n.d.). Retrieved January 14, 2020. Available: https://www.solardirect.com/archives/outdoor-lighting/solar/street/area-light/solarinsolation-map.html

[13] Atthasongkhro, J., Wannathong, C., Rajabhat, S., Lad, K. and April, K. (2013). Solar Radiation in Thailand: 1970-2010 Surface (global) solar radiation. Available: http://www.st.sat.psu.ac.th/seminar/Bangkok/pdfs/jarTorSlides.pdf 